\title{
Review: political entrepreneurs by Catherine de Vries and Sara Hobolt
}

\author{
Julia Schulte-Cloos ${ }^{1}$ (D)
}

Accepted: 11 March 2021 / Published online: 7 April 2021

(C) The Author(s) 2021

Party competition in Western Europe has been characterized by disruption, volatility, and change in recent decades. New parties have formed in all countries, while the established parties have lost some of their former electoral support. The formation of new parties has been coupled with challenges to the liberal democratic order and to the representative model of democracy. Attacking the established political actors and articulating their rejection of the existing political system, populist parties from the left and right have widely attracted support. But are these recent disruptions pointing to a future of continuous electoral volatility and constant political renewal? Or will the political challengers rising today warrant political stability in the future?

The book 'Political Entrepreneurs. The rise of challenger parties across Europe' addresses a timely and relevant topic. Catherine de Vries and Sara Hobolt are arguably among the most influential scholars working on party competition in Europe. While a number of studies have addressed the surge of these 'challenger parties' across Europe, one of the key contributions of this book lies in its notion that the rise of political newcomers presents just one side of the coin. To fully understand this rise, the authors convincingly argue, we also need to analyze the resilience of those parties that used to be dominant during the first three decades after WWII. Notwithstanding the breadth of accelerated political change, some of these parties even continue to be dominant today. By drawing attention to the remarkable resilience of such dominant parties, which tends to spark much less research efforts than the striking success of political entrepreneurs, the book deepens our understanding of past developments in European politics as much as offering a fruitful framework for future research in this field. De Vries and Hobolt propose to assess political change across Europe by understanding the nature and origin of both party dominance (chapters 3 and 4) and innovation (chapters 5 and 6). They rely on an impressive wealth of different data sources covering up to 19 different Western European countries, presenting a plethora of empirical analyses using cross-sectional survey data,

Julia Schulte-Cloos

Julia.Schulte@1mu.de

1 Geschwister Scholl Institute of Political Science, LMU Munich, München, Germany

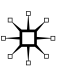


party manifesto data, expert surveys, aggregate electoral data, and in-depth case studies.

Industrial organization theory inspires the authors' theoretical framework and allows them to sketch a brief analogy to the role of well-known contemporary firms in industrial market competition at the beginning of each chapter. These stylized analogies clearly help readers-especially those unfamiliar with the most influential theories of party competition and political change across Europe-to grasp the book's central arguments. The authors conceive of political competition as strategic interactions among parties that are constantly struggling for political power and legislative influence. Political parties are more strategic actors than sociological carriers of (changing) political preferences and political demands in contemporary societies across Western Europe (p. 45). This strategic notion of party competition finds reflection in the way the authors define challenger parties. Parties that have not yet been part of a national cabinet are considered political entrepreneurs (p. 20). Having once participated in national government, parties like the German Greens or the Austrian populist radical right FPÖ lose their status as challengers (p. 138).

While the authors define challenger parties based on a lack of any national government experience, their empirical designs still speak directly to the work of other scholars who define challenger parties based on their programmatic positions in a two dimensional political space [e.g., Adams et al. (2006), Abou-Chadi (2016), Kriesi and Schulte-Cloos (2020)]. The degree of 'issue entrepreneurship' that can boost a challenger party's electoral prospects is understood as a function of the programmatic emphasis that a party places on issues that do not map on the left-right dimension of political conflict and instead are 'appropriable' (p. 119). While the 'traditional' left-right dimension revolves around questions of redistribution, the issues that help challenger parties appeal to voters revolve around questions of "new politics' that map on the cultural dimension: immigration, European integration, and environmental policies. These issues feature not only more prominently in the party manifestos of challenger parties than in the party manifestos of dominant parties (chapter 5), data from the European Election Study 2014 show that citizens who intend to vote for challenger parties also perceive immigration and European integration to be among the most important issues that their countries are facing (chapter 7, p. 193). In chapter 8 , the authors address the ideological heterogeneity among supporters of challenger parties, asking for the political consequences that the presence of challengers might have for the electoral mobilization of certain groups of voters. De Vries and Hobolt demonstrate that the share of right-leaning citizens affirming their intention to participate in an upcoming German state election was significantly greater during more recent (2016-2017) than previous (2010-2012) state elections. This increase, they argue, can be attributed to the first-time electoral presence of the newly established populist right challenger Alternative for Germany (AfD) during these elections, which had a mobilizing effect on right-leaning voters (p. 214f). The disproportionate mobilization of disaffected citizens may, thus, further contribute to the success of a populist right party and give rise to political transformation and change (Schulte-Cloos and Leininger 2021).

What are then, the political strategies of dominant parties that can help them to maintain their position within the electoral market in the face of aspiring political 
entrepreneurs? Just as challenger parties may exploit the mobilization of appropriable issues to cater voters' interests, dominant parties have strategies to 'safeguard their market power' (p. 5). According to manifesto data from the Comparative Manifesto Project (p. 94), most dominant parties from the center-left and center-right still occupy a moderate position on the left-right dimension. Thus, they may exploit their programmatically moderate position to address the policies that typically still matter to a majority of voters, while simultaneously trying to retain a distinct outlook on related redistributive, economic issues - a strategy called 'distinctive convergence' (p.90f). In addition, dominant center-left and center-right parties also benefit from their experience in office and their record of successful policy implementation ('competence mobilization'). Drawing on British and German national election studies, the authors document that between 2000 and 2017, continuously, more than half of German and British respondents believed that the respective dominant center-left or center-right party was the party best at handling the issue most important to them (p. 104). The authors take this finding to suggest that (center) dominant parties' record of government experience acts as an important heuristic to voters when engaging in electoral decision making (p. 104), an effect similar to the frequently studied 'incumbency advantage' in US congressional elections (e.g., Gelman and King 1990). Finally, dominant parties have an electoral advantage through their agenda setting power and their capacity to shape the type and kind of issues that are occupying the minds of voters-and more importantly, those issues that are kept off their minds ('issue avoidance'). The authors show that current dominant parties dedicate significantly less attention to divisive issues of 'new politics' than challenger parties (p. 126), a finding that raises an interesting question. Will the highly 'appropriable' issues that political entrepreneurs have mobilized over the past decades continue to present a recipe for their electoral success once they have participated in government and have become a dominant party themselves? The book, thus, paves the way for promising future research.

'Political Entrepreneurs. The rise of challenger parties across Europe' is an excellent source for students and scholars alike who are interested in understanding European party competition and voting behavior. More than only broadening our understanding of the rise of challenger parties across Europe, the book's original and novel theoretical framework around party dominance and innovation also enriches the literature on comparative politics, more generally. De Vries and Hobolt provide a wealth of clear and accessible analyses, shedding light on the nature and origin of patterns of political stability and change in contemporary Western European party systems. Their book presents an exceptional contribution to research on European party competition that will unquestionably be a focal point of reference for any future research in this field.

Funding Open Access funding enabled and organized by Projekt DEAL.

\section{Declarations}

Conflict of interest The corresponding author states that there is no conflict of interest. 
Open Access This article is licensed under a Creative Commons Attribution 4.0 International License, which permits use, sharing, adaptation, distribution and reproduction in any medium or format, as long as you give appropriate credit to the original author(s) and the source, provide a link to the Creative Commons licence, and indicate if changes were made. The images or other third party material in this article are included in the article's Creative Commons licence, unless indicated otherwise in a credit line to the material. If material is not included in the article's Creative Commons licence and your intended use is not permitted by statutory regulation or exceeds the permitted use, you will need to obtain permission directly from the copyright holder. To view a copy of this licence, visit http://creativecommons.org/licen ses/by/4.0/.

\section{References}

Abou-Chadi, T. 2016. Niche party success and mainstream party policy shifts-how green and radical right parties differ in their impact. British Journal of Political Science 462: 417-436.

Adams, J., M. Clark, L. Ezrow, and G. Glasgow. 2006. Are niche parties fundamentally different from mainstream parties? The causes and the electoral consequences of western European parties' policy shifts, 1976-1998. American Journal of Political Science 503: 513-529.

Gelman, A., and G. King. 1990. Estimating incumbency advantage without bias. American Journal of Political Science 34: 1142-1164.

Kriesi, H., and J. Schulte-Cloos. 2020. Support for radical parties in western europe: Structural conflicts and political dynamics. Electoral Studies 65: 102-138.

Schulte-Cloos, Julia, and Arndt Leininger. 2021. Electoral participation, political disaffection, and the rise of the populist radical right. Party Politics. https://doi.org/10.1177/1354068820985186.

Publisher's Note Springer Nature remains neutral with regard to jurisdictional claims in published maps and institutional affiliations. 